\title{
Early arrival of Southern Source Water in the deep North Atlantic prior to Heinrich event 2
}

\author{
Marcus Gutjahr ${ }^{1,2}$ and Jörg Lippold ${ }^{3}$ \\ Received 10 January 2011; revised 25 May 2011; accepted 31 May 2011; published 25 June 2011.
}

[1] The Atlantic Meridional Overturning Circulation (AMOC) plays an important role in the Northern Hemisphere climate system. Significant interest went into the question of how excessive freshwater input through melting of continental ice can affect its overturning vigor and, hence, heat supply, to higher northern latitudes. Such forcing can be tested by investigating its behavior during extreme iceberg discharge events into the open North Atlantic during the last glacial period, the so-called Heinrich events (HE). Here we present neodymium $(\mathrm{Nd})$ isotope compositions of past seawater, a sensitive chemical water mass tag, extracted from sediments of Ocean Drilling Program Site 1063 in the western North Atlantic (Bermuda Rise), covering the period surrounding HE 2, the Last Glacial Maximum, and the early deglaciation. These data are compared with a record of the kinematic circulation tracer $\left({ }^{231} \mathrm{~Pa} /{ }^{230} \mathrm{Th}\right)_{\mathrm{xs}}$ extracted from the same sediment core. Both tracers indicate significant circulation changes preceding intense ice rafting during HE 2 by almost 2 kyr. Moreover, the Nd isotope record suggests the presence of deeply ventilating North Atlantic Deep Water early during Marine Isotope Stage 2 until it was replaced by Southern Source Water at $\sim 27 \mathrm{ka}$. The early switch to high $(\mathrm{Pa} / \mathrm{Th})_{\mathrm{xs}}$ and radiogenic $\varepsilon_{\mathrm{Nd}}$ in relation to intensified ice rafting during HE 2 suggests that ice rafting into the open North Atlantic during major HE 2 was preceded by an early change of the AMOC. This opens the possibility that variations in AMOC contributed to or even triggered the ice sheet instability rather than merely responding to it.

Citation: Gutjahr, M., and J. Lippold (2011), Early arrival of Southern Source Water in the deep North Atlantic prior to Heinrich event 2, Paleoceanography, 26, PA2101, doi:10.1029/2011PA002114.

\section{Introduction}

[2] The vigor of Atlantic Meridional Overturning Circulation (AMOC) is an integral part of Earth's heat redistribution strongly affecting the climate in both Eurasia and North America [Rahmstorf, 2002]. The strength of its overturning varied through the last glacial cycle(s) and current understanding regards highly elevated freshwater inputs to deepwater formation sites of paramount importance for deteriorations of the system [Hemming, 2004]. The North Atlantic region repeatedly experienced extreme ice rafting Heinrich Events (HE) toward the end of Heinrich Stadials (HS) at near-regular intervals during glaciations of the Pleistocene [McManus et al., 1999; Hodell et al., 2008], although those of the last glacial cycle are clearly the best studied [Hemming, 2004]. During these events large amounts of freshwater were transferred to North Atlantic Deep Water

\footnotetext{
${ }^{1}$ Bristol Isotope Group, Department of Earth Sciences, University of Bristol, Bristol, UK.

${ }^{2}$ Now at School of Ocean and Earth Sciences, National Oceanography Centre, University of Southampton, Southampton, UK.

${ }^{3}$ Heidelberg Academy of Sciences, Institute of Environmental Physics, University of Heidelberg, Heidelberg, Germany.

Copyright 2011 by the American Geophysical Union. 0883-8305/11/2011PA002114
}

(NADW) formation regions providing a possible trigger for a weakening or a shutdown of AMOC during HEs. Evidence from various paleoceanographic tracers suggest that the AMOC was strongly diminished during these events [Sarnthein et al., 1994; Rahmstorf, 2002; McManus et al., 2004]. Although such freshwater hosing scenarios are commonly seen as the source of major North Atlantic MOC changes [Broecker, 2003], increasingly appearing evidence hints at the possibility that intense ice rafting during Heinrich stadials may only be the result of preceding water mass changes [Zahn et al., 1997; Moros et al., 2002; Clark et al., 2007; Alvarez-Solas et al., 2010; Gutjahr et al., 2010].

[3] In this contribution we present new North Atlantic bottom water reconstructions suggesting that ice rafting during HE 2 in HS $2(26-23 \mathrm{ka})$ centered at around $25 \mathrm{ka}$ was the result of preceding water mass changes, albeit ice rafting likely reinforced slowdown of the AMOC through additional freshwater contributions to North Atlantic Deep Water formation sites. These results are obtained from $\mathrm{Nd}$ isotope compositions extracted from sedimentary $\mathrm{Fe}-\mathrm{Mn}$ oxyhydroxides that are combined with records of the activity ratio of seawater-derived (unsupported) ${ }^{231} \mathrm{~Pa}$ to ${ }^{230} \mathrm{Th}(\mathrm{Pa} / \mathrm{Th}$ hereafter) from identical Ocean Drilling Program (ODP) site 1063 on the Bermuda Rise in the North Atlantic [Lippold et al., 2009]. Furthermore, by setting the Bermuda Rise $\mathrm{Pa} / \mathrm{Th}$ 
record in context with an equatorial intermediate water mass record from the Brazil margin [Pahnke et al., 2008], a mechanism can be proposed that lead to the intensified melting of marine-based continental ice sheets and ice rafted debris (IRD) deposition during HE 2 together with intermediate and deep water mass changes seen in our $\mathrm{Pa} / \mathrm{Th}$ and $\mathrm{Nd}$ isotope records.

\subsection{Nd Isotopes and $\mathrm{Pa} / \mathrm{Th}$ as Water Mass Provenance and Circulation Proxies}

[4] Neodymium $(\mathrm{Nd})$ isotopes are a sensitive tracer for past water mass mixing in the North Atlantic given the oceanic residence time of $\mathrm{Nd}$ on the order of 350-500 years and distinct $\mathrm{Nd}$ isotope composition of the major water masses involved [Piepgras and Wasserburg, 1987; von Blanckenburg, 1999; Tachikawa et al., 2003; Lacan and Jeandel, 2005a; Piotrowski et al., 2005; van de Flierdt et al., 2006; Arsouze et al., 2009]. Dissolved $\mathrm{Nd}$ is mainly supplied to the oceans via riverine continental input and boundary exchange processes along continental margins [Frank, 2002; Goldstein and Hemming, 2003; Lacan and Jeandel, 2005b]. This supply mechanism makes $\mathrm{Nd}$ isotopes an excellent tracer of water mass provenance [Jeandel et al., 2007]. The key difference between the major water masses in the North Atlantic is the observation of significantly less radiogenic (lower) $\varepsilon_{\mathrm{Nd}}$ (representing the ${ }^{143} \mathrm{Nd} /{ }^{144} \mathrm{Nd}$ deviation of a sample relative to chondrite uniform reservoir in parts per $10^{4}$ ) seen in NADW compared with deep water of Southern Hemisphere origin (Southern Source Water, SSW). While short-term (millennial-scale) variations in the glacial North Atlantic end-member composition may have occurred due to potentially reduced contributions of Labrador Seawater to NADW during the LGM [Gutjahr et al., 2008], the laser ablation data on ferromanganese crust BM1969.05 of Foster et al. [2007] make longer term shifts in the North Atlantic end-member composition unlikely. Hence, the longer term glacial NADW $\varepsilon_{\mathrm{Nd}}$ likely remained close to its modern composition [Foster et al., 2007]. The bottom water $\mathrm{Nd}$ isotope signature can be extracted from either biogenic [Klevenz et al., 2008; van de Flierdt et al., 2010] or authigenic sedimentary phases [Bayon et al., 2002; Martin and Scher, 2004; Piotrowski et al., 2005; Gutjahr et al., 2007]. In the latter case the $\mathrm{Nd}$ isotopic signature is incorporated into fish teeth or authigenic Fe-Mn oxyhydroxides during early burial in the top few centimeters of the sediments [Haley et al., 2004], thereby preserving a bottom water $\mathrm{Nd}$ isotope signature in suitable abyssal oceanic settings. Protactinium-231 and thorium-230, both produced at a constant rate through radioactive decay from their parent isotopes ${ }^{235} \mathrm{U}$ and ${ }^{234} \mathrm{U}$, scavenged onto sinking particles and measured in marine sediments have been increasingly used as a kinematic circulation proxy in the Atlantic Ocean over the past years [McManus et al., 2004; Thomas et al., 2006; Gherardi et al., 2009]. The basis for the use of this proxy is a net advective export of less particle reactive ${ }^{231} \mathrm{~Pa}$ over ${ }^{230} \mathrm{Th}$ with water masses from the Atlantic to the Southern Ocean. However, $\mathrm{Pa} / \mathrm{Th}$ cannot be used as a stand-alone proxy since it is also affected by changes in bioproductivity [Chase et al., 2002; Bradtmiller et al., 2007; Keigwin and Boyle, 2008; Lippold et al., 2009]. The combined use of $\mathrm{Nd}$ isotopes, which are not affected by productivity, and $\mathrm{Pa} / \mathrm{Th}$ from identical sediment core samples allows to obtain information about both the rate of overturning circulation and the water mass provenance.

\subsection{Glacial and Deglacial North Atlantic Water Mass Reconstructions}

[5] Ample evidence from a variety of proxies suggests that the water mass distribution in the glacial North Atlantic was significantly different from the modern situation [LynchStieglitz et al., 2007]. While NADW occupies most of the water column below $1000 \mathrm{~m}$ in the western North Atlantic today, the deeper parts below about 2500 to $3000 \mathrm{~m}$ were dominated by deep waters advected from the Southern Ocean (SSW) during the Last Glacial Maximum (LGM) [Curry and Oppo, 2005; Lynch-Stieglitz et al., 2007]. Glacial and deglacial SSW had a significantly more radiogenic (higher) Nd isotope signature than NADW resulting in bottom water compositions in the NW Atlantic more than three $\varepsilon_{\mathrm{Nd}}$ units more radiogenic than at present $\left(\varepsilon_{\mathrm{Nd}}\right.$ of -10 compared with -13.5$)$ [Gutjahr et al., 2008; Roberts et al., 2010]. In the vicinity of the Blake Ridge in the NW Atlantic Nd isotope data documented deeply ventilating NADW only after the termination of the Younger Dryas ( 12.9-11.7 ka) [Gutjahr et al., 2008], whereas at the Bermuda Rise a brief first deglacial interval of deep NADW ventilation was already found as early as the Bølling-Allerød interstadial ( 14.6-12.9 ka) [Roberts et al., 2010]. Reconstructions of the deep North Atlantic water column structure preceding the LGM are chronologically less well resolved. This is due to (1) scarcity of epibenthic foraminifera used for carbon isotopic bottom water reconstructions in fully glacial deep marine sediments and (2) due to increasing age uncertainties when using radiocarbon-dated planktic foraminifera as a chronostratigraphic marker. Possibly SSW occupied the deep North Atlantic for a significant fraction of the last glacial cycle in a manner not too dissimilar to the LGM situation [Sarnthein et al., 1994; Rahmstorf, 2002].

\section{Methods}

\subsection{Analytical Approach}

[6] Bermuda Rise ODP Leg 172 sediment core from Site $1063\left(33^{\circ} 41^{\prime} \mathrm{N}, 57^{\circ} 37^{\prime} \mathrm{W}\right.$, water depth $\left.4584 \mathrm{~m}\right)$ in the western North Atlantic was selected for $\mathrm{Nd}$ isotopic analyses spanning the interval from 30 to $15 \mathrm{ka}$. The Fe-Mn oxyhydroxidebound bottom water $\mathrm{Nd}$ isotope signal was extracted from the sediments applying a sequential leaching technique [Gutjahr et al., 2007] at the University of Heidelberg and the University of Bristol in three different analytical sessions in 2009. Subsequent separation and purification of $\mathrm{Nd}$ from the Fe-Mn oxyhydroxide matrix followed standard procedures [Cohen et al., 1988] and was carried out at the University of Bristol. The total procedural $\mathrm{Nd}$ blank was in the range of 13 to $94 \mathrm{pg}(\mathrm{n}=3)$ and hence insignificant. Neodymium isotope analyses were carried out with a Thermo Finnigan Neptune MC-ICPMS at the Bristol Isotope Group of the University of Bristol, UK. Correction of the instrumentinduced mass bias followed Vance and Thirlwall [2002] through adjusting to a ${ }^{146} \mathrm{Nd} /{ }^{144} \mathrm{Nd}$ to 0.7219 . Mass-bias corrected ratios were normalized to the given ${ }^{143} \mathrm{Nd} /{ }^{144} \mathrm{Nd}$ of the La Jolla standard of 0.511856 . External mass spectrometric reproducibility of the $\mathrm{Nd}$ isotope measurements at ${ }^{144} \mathrm{Nd}$ ion currents of around $7 \times 10^{-11} \mathrm{~A}$ is better than $0.15 \varepsilon_{\mathrm{Nd}}$. 


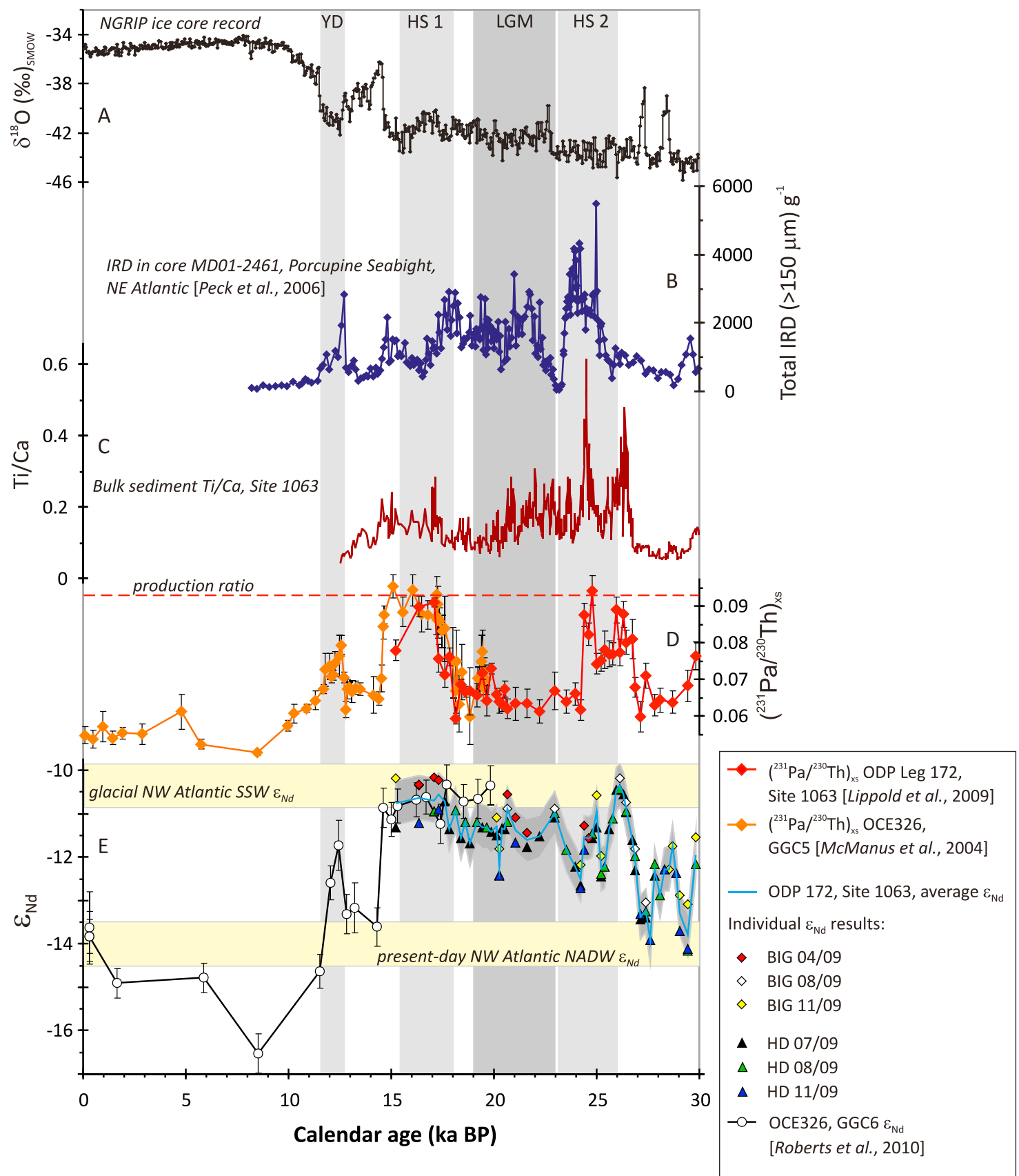

Figure 1. (e) Bermuda Rise bottom water ${ }^{143} \mathrm{Nd} /{ }^{144} \mathrm{Nd}$ isotope record covering the past $30 \mathrm{kyr}$, expressed in the $\varepsilon_{\mathrm{Nd}}$ notation, representing the ${ }^{143} \mathrm{Nd} /{ }^{144} \mathrm{Nd}$ deviation of a sample relative to chondrite uniform reservoir in parts per 10,000 . The new $\varepsilon_{\mathrm{Nd}}$ data are presented together with and overlap those of Roberts et al. [2010], which extend from the latest LGM to the present-day and that were obtained by leaching of uncleaned foraminifera instead of bulk sediments. A large number of duplicates were produced in the course of our study and all data points are shown. The average $\mathrm{Nd}$ isotope composition for each sampled sedimentary depth including a gray $0.5 \varepsilon_{\mathrm{Nd}}$ error envelope is also shown for better visibility of the patterns. The horizontal yellow boxes in the Figure $1 \mathrm{e}$ indicate modern NADW $\varepsilon_{\mathrm{Nd}}$ as well as deep northwest Atlantic SSW $\varepsilon_{\mathrm{Nd}}$ during the LGM $\left(\varepsilon_{\mathrm{Nd}}=-10.3 \pm 0.5\right)$ [Gutjahr et al., 2008; Roberts et al., 2010]. (c) Bulk sediment Ti/Ca [Lippold et al., 2009] and (b) NE Atlantic IRD records from the Porcupine Seabight [Peck et al., 2006] are shown for comparison. (d) Pa/Th data are from ODP Site 1063 [Lippold et al., 2009] and OCE326 GGC5 [McManus et al., 2004]. (a) NGRIP ice core oxygen isotope record [North Greenland Ice Core Project Members, 2004]. Timing and duration of Heinrich Stadials 1 and 2 were adopted from Bard et al. [2000] and Barker et al. [2009]. 


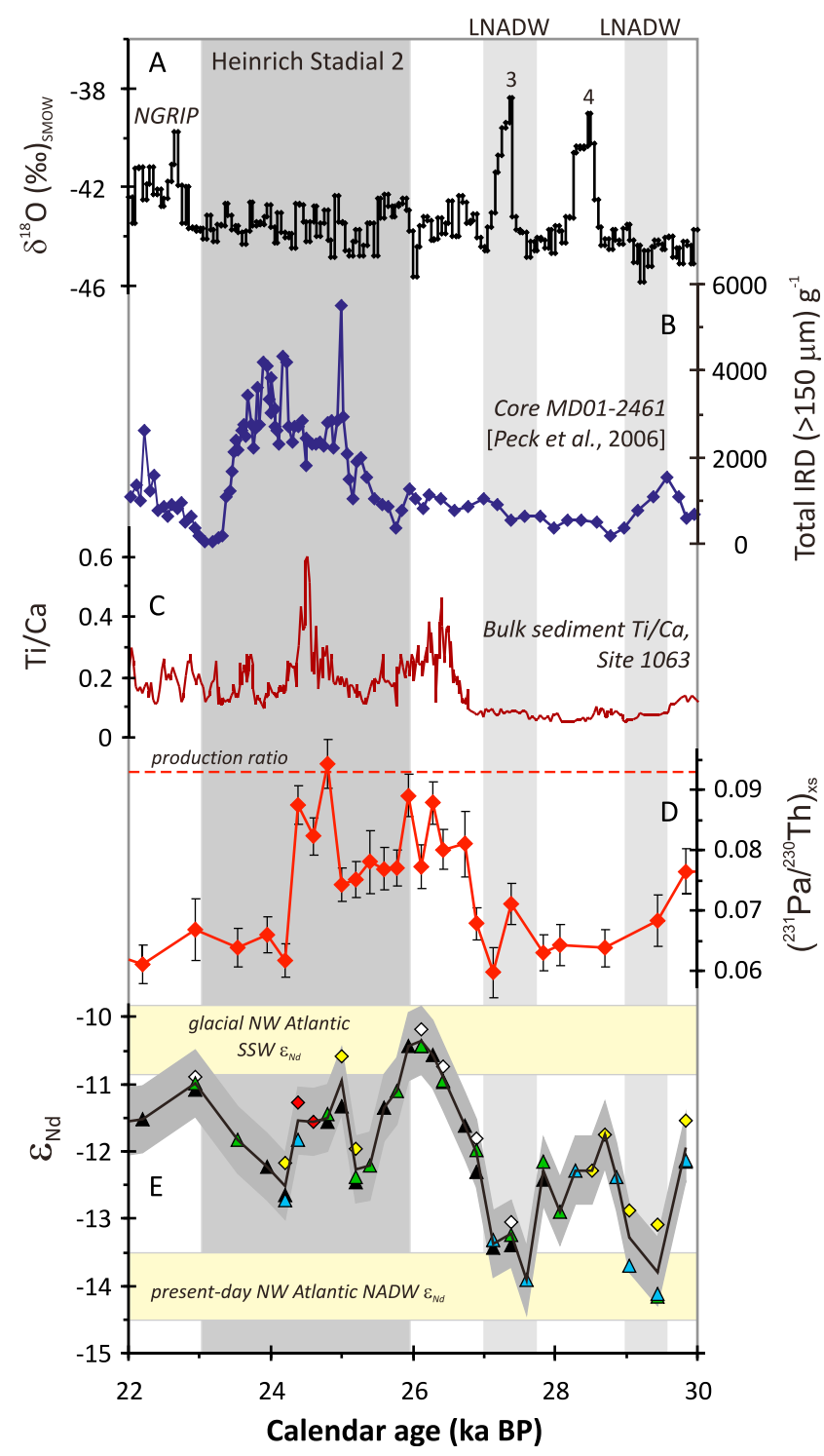

Figure 2. The time slice surrounding Heinrich stadial and Heinrich event 2 (30-22 ka) shown at expanded scale to document the excellent agreement of the $\mathrm{Nd}$ and $\mathrm{Pa} / \mathrm{Th}$ isotope records. All symbols are similar to Figure 1. Timing and duration of HS 2 are as defined by Bard et al. [2000]. LNADW (light gray boxes) refers to times of lower North Atlantic Deep Water presence at the Bermuda Rise according to unradiogenic $\mathrm{Nd}$ isotope compositions observed here preceding HS2.

Duplicate samples displayed in Figures 1 and 2 and Table S1 (in the auxiliary material) were processed and measured separately in three individual sessions in both labs, respectively. ${ }^{1}$

\subsection{Chronology of ODP Site 1063}

[7] The previous age model of the last $40 \mathrm{kyr}$ for ODP Site 1063 was established by correlation of the $\mathrm{CaCO}_{3}$ content of the sediment with the $\mathrm{CaCO}_{3}$ content of the nearby core GPC5 [Keigwin and Jones, 1994; Lippold et al.,

\footnotetext{
${ }^{1}$ Auxiliary materials are available in the HTML. doi:10.1029/ 2011PA002114
}

2009]. The age model of core GPC5 in turn is based on 32 mixed planktonic foraminiferal ${ }^{14} \mathrm{C}$ dates. The ${ }^{14} \mathrm{C}$ ages were corrected for their reservoir age, which was assumed to be constant at 400 years and calibrated with data of Fairbanks et al. [2005]. Comparison to the calibration with INTCAL09 did not yield significant differences [Reimer et al., 2009].

[8] Further, an alternative high-resolution age model for ODP Site 1063 has been developed. This is based on the observation of an extremely strong signature of Dansgaard/ Oeschger $(\mathrm{D} / \mathrm{O})$ cycles in sediment properties, chiefly $\mathrm{CaCO}_{3}$ content, in the sediments, recorded due to the high sedimentation rate of this core of more than $25 \mathrm{~cm} / \mathrm{kyr}$ during the studied time interval [see also in Lippold et al., 2009, Figures 3 and 4a]. Lippold et al. [2009] have developed a new age model for ODP Site 1063, based on tuning of the carbonate content with the NGRIP ice core (GICC05 time scale [Svensson et al., 2006]). This enabled these authors to identify tie points over the whole depth of the core (on average each $\sim 2300$ years one tie point). As a result, a second age model could be established between $\sim 12$ to $40 \mathrm{ka}$, which is in very good agreement to the first approach. Thus, the age model of ODP Site 1063 for this time period can be considered to be very robust.

[9] The age model employed for core MD01-2461 by Peck et al. [2006] that we use for comparative purposes in Figures 1 and 2 is derived from tuning the N. pachyderma sin. $\%$ record to GISPII $\delta^{18} \mathrm{O}$ profile providing a robust stratigraphy, which is comparable with the Greenland ice core record and palaeoceanographic profiles from other North Atlantic core sites [Veiga-Pires and Hillaire-Marcel, 1999]. Further details can be found in the work by Peck et al. [2006].

\section{Results and Discussion}

[10] In order to demonstrate the reproducibility of the Bermuda Rise record all individual $\mathrm{Nd}$ isotope results are shown in Figures 1 and 2, alongside with the corresponding average $\varepsilon_{\text {Nd }}$ per sampled depth (see also Table S1). Over the past $30 \mathrm{kyr}$ the bottom water $\mathrm{Nd}$ isotope signature, as recorded in Bermuda Rise Fe-Mn oxyhydroxides, underwent significant variability (Figure 1). The deglacial interval, in which our sediment-derived Fe-Mn oxyhydroxide $\mathrm{Nd}$ isotope record overlaps with the record of Roberts et al. [2010], shows excellent agreement confirming the reliability of the two slightly different approaches used. While $\varepsilon_{\mathrm{Nd}}$ are quite radiogenic (more positive) and less variable between 23 and $15 \mathrm{ka}$, several short-term changes can be observed during HS 2. The largest shift in our record on the order of three $\varepsilon_{\mathrm{Nd}}$ is seen at $\sim 27 \mathrm{ka}$ (Figures 1 and 2).

[11] In terms of water masses, the $\mathrm{Nd}$ isotope data of ODP Site 1063 recorded the presence of glacial SSW in the deep North Atlantic during HS 1, the early deglaciation and the LGM (Figure 1e). Heinrich stadial 1 and a brief interval immediately preceding HS 2 (at $\sim 26 \mathrm{ka}$ ) recorded the purest (most radiogenic) SSW compositions. Strikingly, however, our record also shows brief intervals of unradiogenic $\varepsilon_{\mathrm{Nd}}$ typical for deeply ventilating late Holocene NADW (Figures 1 and 2), which preceded the LGM and HS 2. Both the water mass variability and the presence of NADW in $4 \mathrm{~km}$ water depth during Marine Isotope Stage (MIS) 2 have not been reported to date and deserve particular attention. 


\subsection{Deep NADW Ventilation Preceding Heinrich Stadial 2}

[12] The presence of deeply ventilating NADW during the early stage of MIS 2 is surprising given the glacial boundary conditions, which should have led to the formation of a shallower overturning circulation cell [Sarnthein et al., 1994; Rahmstorf, 2002]. Based on sedimentary pore fluid reconstructions, Adkins et al. [2002] suggested that near-freezing salty deep waters that advected from the Southern Ocean replaced the cold but fresher NADW in the abyssal North Atlantic during the LGM. Yet it remains unresolved whether hydrographic conditions were similar for the time period preceding HS 2 during early MIS 2. Replacement of northern sourced deep water by SSW is not only indicated by the $\mathrm{Nd}$ isotope record (Figure 2e) but also by high-resolution elemental records obtained from sediments of ODP Site 1063 (Figure 2c). These reveal concomitant changes in the bulk sedimentary titanium to calcium ratio $(\mathrm{Ti} / \mathrm{Ca})$ alongside with the $\mathrm{Pa} / \mathrm{Th}$ and $\mathrm{Nd}$ isotopic changes. In glacial abyssal marine settings variations in bulk sedimentary $\mathrm{Ti} / \mathrm{Ca}$ can be driven by either variable relative terrigenous material delivery or alternatively partial dissolution of previously deposited carbonate. Since the variations seen at ODP Site 1063 are decoupled from changes in sedimentation rates [Lippold et al., 2009] the changing $\mathrm{Ti} / \mathrm{Ca}$ at ODP Site 1063 can be attributed to inflow of more corrosive SSW leading to a temporary rise of the North Atlantic lysocline. Our observation of deeply ventilating NADW in the subtropical Northwest Atlantic early during MIS 2 and preceding HS 2 contrasts with common understanding of glacial AMOC [Sarnthein et al., 1994; Rahmstorf, 2002] and calls for modeling and comparative proxy data investigations.

\subsection{Implications of Coupled $\mathrm{Pa} / \mathrm{Th}$ and $\varepsilon_{\mathrm{Nd}}$ Changes Preceding HE 2}

[13] The changes observed in our $\mathrm{Nd}$ isotope record covaried tightly with changes in $\mathrm{Pa} / \mathrm{Th}$ surrounding $\mathrm{HE} 2$ (Figure 2). Whereas only the end of the $\mathrm{Pa} / \mathrm{Th}$ excursion surrounding HE 1 is resolved in the $\mathrm{Nd}$ isotope record, both the initiation and the end of the water mass changes preceding HE 2 were clearly recorded with both proxies. A key observation is that the water mass reorganization clearly predated Northwest European Ice Sheets (NWEIS)-derived Ice Rafted Debris (IRD) deposition during HE 2 by approximately 2 kyr. Since major ice rafting during HE 2 first initiated from the NWEIS and was only followed by Laurentide ice sheet-derived IRD deposition [Scourse et al., 2000; Hemming, 2004; Peck et al., 2006; Scourse et al., 2009] we compare our record to a NWEIS-derived IRD record (Figures 1 and 2). The difference in timing between changes in water mass properties (Figures 2c-2e) and NWEIS-derived IRD deposition (Figure 2b) suggests that processes other than intensified iceberg discharge from the Laurentide or NW European ice sheets caused the changes in water mass composition and probably also in the strength of overturning circulation.

[14] Nevertheless, elevated freshwater input through enhanced iceberg calving into key areas of North Atlantic Deep Water formation is the prime candidate capable of triggering major water mass reorganizations [Hemming, 2004; Peck et al., 2006]. The northwest European ice sheets were close to their maximum volume [Scourse et al., 2009; Lambeck et al., 2010] and likely large enough early during MIS 2 to offset the stability of Atlantic MOC through highly elevated iceberg discharge that was recorded in the Northeast Atlantic during this time [Peck et al., 2006; Scourse et al., 2009]. Yet whether significant freshwater addition through excessive iceberg calving to the subpolar North Atlantic led to the observed changes in deep water circulation is questionable. As evidenced by the remote Greenland ice core climate records, water mass reorganization surrounding HE 2 occurred during apparently stable glacial atmospheric conditions (Figures 1 and 2) [Grootes et al., 1993; North Greenland Ice Core Project Members, 2004]. Despite this apparent climatic stability, northeast Atlantic IRD records invoke significantly enhanced iceberg calving rates from the NWEIS during the time of our $\mathrm{Nd}$ isotope and $\mathrm{Pa} / \mathrm{Th}$ excursion [Scourse et al., 2009]. Importantly, however, these sedimentary IRD maxima lag the deep North Atlantic water mass change as documented by $\mathrm{Pa} / \mathrm{Th}, \varepsilon_{\mathrm{Nd}}$ and $\mathrm{Ti} / \mathrm{Ca}$, even if we assign a conservative error estimate on the order of $1 \mathrm{kyr}$. Therefore, if the influx of SSW into the deep North Atlantic was related to the HE 2 ice rafting event, then it should only be related to the cause but not be the consequence of catastrophic ice sheet disintegration. This conclusion depends on the reliability of absolute chronologies of the two cores presented here and requires confirmation through future studies. Conversely, we want to mention in this context that a similar lead-lag relationship was observed for water mass changes with increasing presence of SSW along the deeper Blake Ridge preceding HE 4 [Gutjahr et al., 2010]. The phasing between elevated IRD deposition and SSW incursion in our data profiles is different for HE 1 and the YD (Figure 1). Heinrich event 1 followed shortly after the LGM during the early deglaciation while Northern Hemisphere summer insolation already increased [Alley and Clark, 1999]. The YD took place during the late deglaciation and likely involved a rerouting of meltwater flow from a Mississippi runoff route to the NW Atlantic [e.g., Kennett and Shackleton, 1975; Licciardi et al., 1999; Clark et al., 2001; Carlson, 2008; Kurzweil et al., 2010] or the Arctic [Tarasov and Peltier, 2005]. Hence the climatic boundary conditions and freshwater perturbation scenarios were different for HE 1 and the YD from those extant during HE 2.

\subsection{Evidence for Intermediate North Atlantic Water Mass Changes at $27 \mathrm{ka}$}

[15] $\mathrm{Pa}$ /Th close to the production ratio do not necessarily reflect circulation changes [Chase et al., 2002; Bradtmiller et al., 2007; Keigwin and Boyle, 2008] but would also be consistent with the presence of silicate-rich surface and intermediate waters early during HS 2 and HS 1 leading to elevated opal productivity and associated preferential $\mathrm{Pa}$ scavenging. This is evidenced by high diatom abundances at ODP Site 1063 [Lippold et al., 2009] and at the nearby core OCE326-GGC6 from the Bermuda Rise [Gil et al., 2009]. The Bermuda Rise $\mathrm{Nd}$ isotope record can only resolve the origin of deep waters and additional information is required to also resolve water mass changes in the shallow and intermediate glacial North Atlantic during the $\mathrm{Pa} / \mathrm{Th}$ excursions observed for HE 2. Modified Antarctic Intermediate Water (AAIW) advected from the Southern Ocean is the 

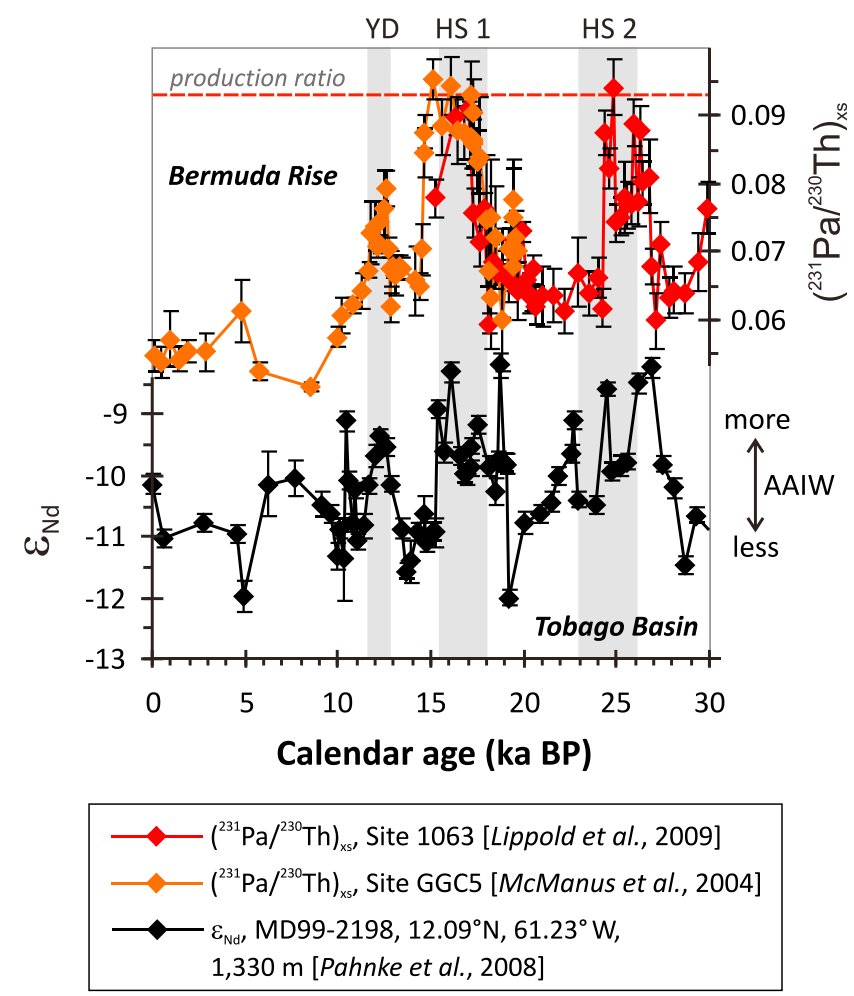

Figure 3. (top) Bermuda Rise $\mathrm{Pa} / \mathrm{Th}$ records [McManus et al., 2004; Lippold et al., 2009] compared with (bottom) equatorial Atlantic Tobago Basin Nd isotope record [Pahnke et al., 2008], for which higher $\varepsilon_{\mathrm{Nd}}$ was interpreted as intensified Antarctic Intermediate Water advection toward the North Atlantic [Pahnke et al., 2008].

most likely water mass to provide additional nutrients to near-surface waters. Both Robinson et al. [2005], as well as very recently Thornalley et al. [2011] also presented evidence for temporary AAIW water presence in the deglacial North Atlantic coincident with HS 1 based on very old intermediate water radiocarbon ventilation ages.

[16] Increased northward flow of AAIW has indeed been observed in Tobago Basin core MD99-2198 (1330 m water depth) in the subtropical North Atlantic during both Heinrich stadials [Pahnke et al., 2008]. Comparing this equatorial West Atlantic intermediate water $\mathrm{Nd}$ isotope record to Bermuda Rise $\mathrm{Pa} / \mathrm{Th}$ reveals a tentative lead-lag relationship during HE 2 with the Tobago Basin water mass changes marginally leading the Bermuda Rise records (Figure 3). The inflow of SSW in the deep North Atlantic recorded in the Bermuda Rise Nd isotope record was therefore more or less coincidental with increased AAIW and Southern Component Water advection to the North Atlantic at intermediate depths. The invasion of both water masses preceded HE 2 IRD deposition (Figures 2 and 3). If intensified presence of low latitude surface and intermediate waters during HE 2 in turn supplied more heat to the subsurface high-latitude North Atlantic this would have had an amplifying effect in the initiation of Heinrich IRD events by subsurface melting from underneath marine-based continental ice shelves [cf. Clark et al., 2007]. Basal melting of marine-based continental ice is a currently very active process observed along both the
West Antarctic Continental Margin [Payne et al., 2004; Shepherd et al., 2004] and Greenland [Rignot et al., 2010]. If low-latitude derived intermediate or near-surface waters supplied additional heat to the high latitude glacial North Atlantic, this could have had a similar effect on marine based ice sheets during Heinrich stadials. Should this turn out to be correct, then the origin for these major hydrographic reorganizations and the massive disintegration of marine-based continental ice sheets during HEs, however, would consequently have to be identified in the Southern Ocean and not the North Atlantic [e.g., Brathauer and Abelmann, 1999].

\subsection{Changing AMOC Modes From a Pa/Th- $\varepsilon_{\mathrm{Nd}}$ Perspective}

[17] The Bermuda Rise Pa/Th record also confirms active AMOC during the LGM. Although this tracer may be offset toward the production ratio by high diatom productivity and may thus not have reliably traced overturning circulation during Heinrich Stadials, there is no reason to question the validity of low $\mathrm{Pa} / \mathrm{Th}$ such as seen during the LGM at low diatom abundance in the water column [Gil et al., 2009; Lippold et al., 2009]. The different modes of glacial, Heinrich stadial and interglacial AMOC can be identified through direct comparison of the Bermuda Rise $\varepsilon_{\mathrm{Nd}}$ with $\mathrm{Pa} / \mathrm{Th}$ (Figure 4). Modern compositions are typical of deep NADW

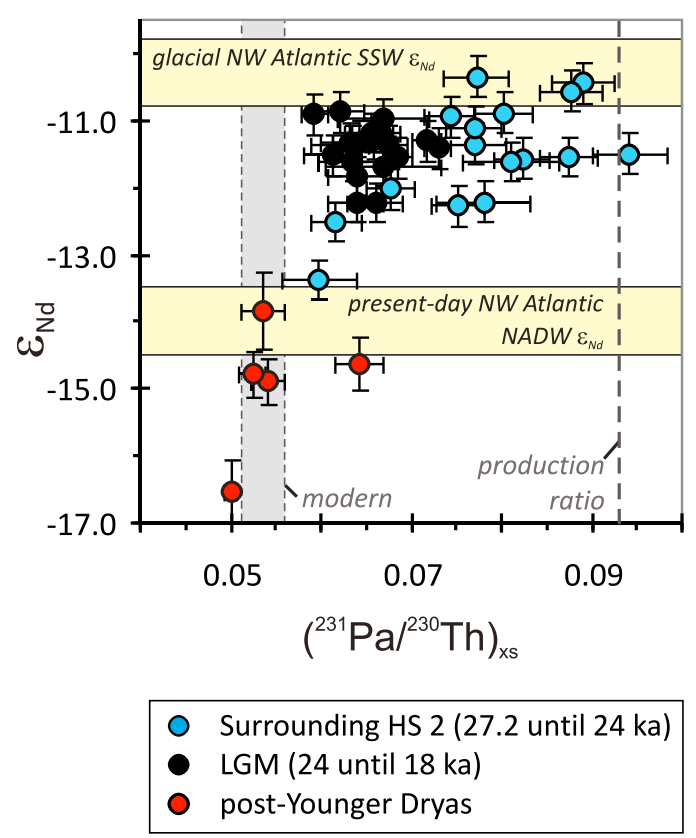

Figure 4. Bermuda Rise Nd isotope compositions versus $\mathrm{Pa} / \mathrm{Th}$ depicted for the Holocene, the LGM, as well as surrounding and preceding HS2. Yellow boxes indicate modern NADW $\varepsilon_{\mathrm{Nd}}$ and deep northwest Atlantic SSW $\varepsilon_{\mathrm{Nd}}$ during the LGM $\left(\varepsilon_{\mathrm{Nd}}=-10.3 \pm 0.5\right)$ [Gutjahr et al., 2008; Roberts et al., 2010]. Left vertical gray box defines the modern $\mathrm{Pa} / \mathrm{Th}$ as measured at $0.48 \mathrm{kyr}$ in core OCE326/GGC5 [McManus et al., 2004], and vertical dashed line highlights the production ratio. Post-Younger Dryas $\mathrm{Pa} / \mathrm{Th}$ and $\varepsilon_{\mathrm{Nd}}$ are from cores OCE326/GGC5 [McManus et al., 2004] and GGC6 [Roberts et al., 2010] and deviate by less than 210 years $(n=5)$. 
ventilation and active overturning, whereas the LGM witnessed active but shallower overturning. The scatter in the data seen surrounding HE 2 (Figure 4) highlights the switches between the presence of NADW and SSW, accompanied either by attenuation of the AMOC or only preferential Pa scavenging by opal.

\subsection{Lower NADW Versus SSW Competition During and Preceding HS 2}

[18] The ODP Site $1063 \mathrm{Nd}$ isotope record suggests a transition into a fully glacial mode of ocean stratification at the onset of the LGM lasting until the end of HS 1 with the deep North Atlantic being continuously situated within SSW (Figures 1 and 4). During HS 2 the situation is not as clear. After the major shift in $\varepsilon_{\mathrm{Nd}}$ toward SSW compositions seen between 27 to $26 \mathrm{ka}$, two smaller excursions to less radiogenic compositions are observed during HE 2 that follow trends in the $\mathrm{Pa} / \mathrm{Th}$ record (Figure 2). We therefore speculate that the relative water mass densities between deep northern and southern sourced waters were likely very similar during HE 2 leading to the observed pattern [cf. Adkins et al., 2002].

[19] Finally, the transition into MIS 2 seen in the $\varepsilon_{\mathrm{Nd}}$ record between 30 to $27 \mathrm{ka}$ holds additional water mass information. Almost modern LNADW $\varepsilon_{\mathrm{Nd}}$ were recorded at $\sim 29 \mathrm{ka}$ and immediately preceding $27 \mathrm{ka}$ (Figure 2e). Before and in between these excursions $\varepsilon_{\mathrm{Nd}}$ tend to more SSWlike compositions. This variability is not reflected in the $\mathrm{Pa} / \mathrm{Th}$ record (Figure $2 \mathrm{~d}$ ). While the second excursion to unradiogenic $\varepsilon_{\text {Nd }}$ corresponds to Greenland Interstadial 3 (Figure 2a), this is not the case for the earlier excursion at $\sim 29 \mathrm{ka}$. We cannot uniquely identify the control over these apparently short-term water mass changes but attribute these to the climatic and hydrographic variability that characterizes MIS 3 and most of the last glacial cycle [McManus et al., 1999]. If these late MIS 3 changes in abyssal water mass presence indeed respond to $\mathrm{D} / \mathrm{O}$ cycles, this pattern would then follow a Northern Hemisphere climate signal.

\section{Conclusions}

[20] The combined Bermuda Rise $\mathrm{Pa} / \mathrm{Th}$ and $\mathrm{Nd}$ isotope data sets from ODP Site 1063 record the transition of North Atlantic MOC into a Heinrich stadial and subsequent LGM mode of ocean stratification that lasted until the termination of $\mathrm{HS} 1$. The $\mathrm{Nd}$ isotope record suggests the presence of Lower NADW during late MIS 3 and early MIS 2 below $4 \mathrm{~km}$ water depth, being replaced by SSW at $\sim 27$ ka approximately 2 kyr before the onset of elevated ice rafting during HE 2. Both the ODP Site $1063 \mathrm{~Pa} / \mathrm{Th}$ as well as the $\mathrm{Nd}$ isotope composition changes significantly preceding HE 2 . Given the coincidence between the Bermuda Rise $\mathrm{Pa} / \mathrm{Th}$ changes and the Brazil margin intermediate water mass changes presented earlier [Pahnke et al., 2008] over this time interval this suggests that not only the deep but also the intermediate North Atlantic witnessed this major water mass change during HE 2. Intensified inflow of modified Antarctic Intermediate Water could in turn provide additional heat required to initiate accelerated basal melting of marine-based continental ice sheets. Our record does not provide information on the connectivity between SSW inflow into the abyssal North Atlantic and apparently increased supply of modified AAIW in intermediate depth.

[21] If highly elevated ice rafting during Heinrich events indeed only were the result and not the cause of major North Atlantic water column reorganizations, as indicated by our data for HE 2, this may require a revision of paleoceanographic models that commonly utilize freshwater hosing into the North Atlantic as the sole trigger inducing collapses of the AMOC. Freshwater input will have a reinforcing effect in slowing down the AMOC, yet controlling factors of the circulation changes may have to be identified elsewhere, most likely in hydrographic and paleoclimatic warming trends in the Southern Ocean. In order to test this hypothesis more fine-scale records with highly accurate chronologies are required within the North Atlantic IRD belt and from the Southern Ocean.

[22] Acknowledgments. This study made use of ODP sediment core material from the Bremen core repository recovered during ODP cruise 172. Funding through DFG grant Li 1815/2 is acknowledged. Constructive comments by Derek Vance, Martin Frank, and Marcus Christl improved an earlier version of the manuscript. Chris Coath is thanked for continuous mass spectrometric support within the Bristol Isotope Group. We are grateful for constructive criticism provided by two anonymous reviewers as well as Rainer Zahn, who is also thanked for swift editorial handling of the manuscript.

\section{References}

Adkins, J. F., K. McIntyre, and D. P. Schrag (2002), The salinity, temperature, and delta O-18 of the glacial deep ocean, Science, 298(5599), 1769-1773, doi:10.1126/science.1076252.

Alley, R. B., and P. U. Clark (1999), The deglaciation of the Northern Hemisphere: A global perspective, Annu. Rev. Earth Planet. Sci., 27, 149-182, doi:10.1146/annurev.earth.27.1.149.

Alvarez-Solas, J., S. Charbit, C. Ritz, D. Paillard, G. Ramstein, and C. Dumas (2010), Links between ocean temperature and iceberg discharge during Heinrich events, Nat. Geosci., 3(2), 122-126, doi:10.1038/ ngeo 752 .

Arsouze, T., J. C. Dutay, F. Lacan, and C. Jeandel (2009), Reconstructing the Nd oceanic cycle using a coupled dynamical-biogeochemical model, Biogeosciences, 6(12), 2829-2846, doi:10.5194/bg-6-2829-2009.

Bard, E., F. Rostek, J. L. Turon, and S. Gendreau (2000), Hydrological impact of Heinrich events in the subtropical northeast Atlantic, Science, 289(5483), 1321-1324, doi:10.1126/science.289.5483.1321.

Barker, S., P. Diz, M. J. Vautravers, J. Pike, G. Knorr, I. R. Hall, and W. S. Broecker (2009), Interhemispheric Atlantic seesaw response during the last deglaciation, Nature, 457(7233), 1097-1102, doi:10.1038/ nature 07770 .

Bayon, G., C. R. German, R. M. Boella, J. A. Milton, R. N. Taylor, and R. W. Nesbitt (2002), An improved method for extracting marine sediment fractions and its application to $\mathrm{Sr}$ and $\mathrm{Nd}$ isotopic analysis, Chem. Geol., 187(3-4), 179-199, doi:10.1016/S0009-2541(01)00416-8.

Bradtmiller, L. I., R. F. Anderson, M. Q. Fleisher, and L. H. Burckle (2007), Opal burial in the equatorial Atlantic Ocean over the last $30 \mathrm{ka}$ : Implications for glacial-interglacial changes in the ocean silicon cycle, Paleoceanography, 22, PA4216, doi:10.1029/2007PA001443.

Brathauer, U., and A. Abelmann (1999), Late Quaternary variations in sea surface temperatures and their relationship to orbital forcing recorded in the Southern Ocean (Atlantic sector), Paleoceanography, 14(2), 135-148, doi:10.1029/1998PA900020.

Broecker, W. S. (2003), Does the trigger for abrupt climate change reside in the ocean or in the atmosphere?, Science, 300(5625), 1519-1522, doi:10.1126/science. 1083797

Carlson, A. E. (2008), Why there was not a Younger Dryas-like event during the penultimate deglaciation, Quat. Sci. Rev., 27(9-10), 882-887, doi:10.1016/j.quascirev.2008.02.004.

Chase, Z., R. F. Anderson, M. Q. Fleisher, and P. W. Kubik (2002), The influence of particle composition and particle flux on scavenging of Th, $\mathrm{Pa}$ and $\mathrm{Be}$ in the ocean, Earth Planet. Sci. Lett., 204(1-2), 215-229, doi:10.1016/S0012-821X(02)00984-6. 
Clark, P. U., S. J. Marshall, G. K. C. Clarke, S. W. Hostetler, J. M. Licciardi, and J. T. Teller (2001), Freshwater forcing of abrupt climate change during the last glaciation, Science, 293(5528), 283-287, doi:10.1126/ science. 1062517.

Clark, P. U., S. W. Hostetler, N. G. Pisias, A. Schmittner, and K. J. Meissner (2007), Mechanisms for an 7-kyr climate and sea-level oscillation during Marine Isotope Stage 3, in Ocean Circulation: Mechanisms and ImpactsPast and Future Changes of Meridional Overturning, Geophys. Monogr. Ser., vol. 173, edited by A. Schmittner, et al., pp. 209-246, AGU, Washington, D. C

Cohen, A. S., R. K. Onions, R. Siegenthaler, and W. L. Griffin (1988), Chronology of the pressure-temperature history recorded by a granulite terrain, Contrib. Mineral. Petrol., 98(3), 303-311, doi:10.1007/ BF00375181.

Curry, W. B., and D. W. Oppo (2005), Glacial water mass geometry and the distribution of $\delta^{13} \mathrm{C}$ of $\Sigma \mathrm{CO}_{2}$ in the western Atlantic Ocean, Paleoceanography, 20, PA1017, doi:10.1029/2004PA001021.

Fairbanks, R. G., R. A. Mortlock, T. C. Chiu, L. Cao, A. Kaplan, T. P. Guilderson, T. W. Fairbanks, A. L. Bloom, P. M. Grootes, and M. J. Nadeau (2005), Radiocarbon calibration curve spanning 0 to 50,000 years BP based on paired ${ }^{230} \mathrm{Th} /{ }^{234} \mathrm{U} /{ }^{238} \mathrm{U}$ and ${ }^{14} \mathrm{C}$ dates on pristine corals, Quat. Sci. Rev., 24(16-17), 1781-1796, doi:10.1016/j.quascirev. 2005.04.007.

Foster, G. L., D. Vance, and J. Prytulak (2007), No change in the neodymium isotope composition of deep water exported from the North Atlantic on glacial-interglacial timescales, Geology, 35(1), 37-40, doi:10.1130/ G23204A.1.

Frank, M. (2002), Radiogenic isotopes: Tracers of past ocean circulation and erosional input, Rev. Geophys., 40(1), 1001, doi:10.1029/ 2000RG000094

Gherardi, J.-M., L. Labeyrie, S. Nave, R. Francois, J. F. McManus, and E. Cortijo (2009), Glacial-interglacial circulation changes inferred from ${ }^{231} \mathrm{~Pa} /{ }^{230} \mathrm{Th}$ sedimentary record in the North Atlantic region, Paleoceanography, 24, PA2204, doi:10.1029/2008PA001696.

Gil, I. M., L. D. Keigwin, and F. G. Abrantes (2009), Deglacial diatom productivity and surface ocean properties over the Bermuda Rise, northeast Sargasso Sea, Paleoceanography, 24, PA4101, doi:10.1029/ 2008PA001729.

Goldstein, S. L., and S. R. Hemming (2003), Long-lived isotopic tracers in oceanography, paleoceanography, and ice-sheet dynamics, Treatise Geochem., 6, 453-489, doi:10.1016/B0-08-043751-6/06179-X.

Grootes, P. M., M. Stuiver, J. W. C. White, S. Johnsen, and J. Jouzel (1993), Comparison of oxygen isotope records from the GISP2 and GRIP Greenland ice cores, Nature, 366(6455), 552-554, doi:10.1038/ $366552 \mathrm{a} 0$.

Gutjahr, M., M. Frank, C. H. Stirling, V. Klemm, T. van de Flierdt, and A. N. Halliday (2007), Reliable extraction of a deepwater trace metal isotope signal from Fe-Mn oxyhydroxide coatings of marine sediments, Chem. Geol., 242(3-4), 351-370, doi:10.1016/j.chemgeo.2007.03.021.

Gutjahr, M., M. Frank, C. H. Stirling, L. D. Keigwin, and A. N. Halliday (2008), Tracing the Nd isotope evolution of North Atlantic Deep and Intermediate Waters in the western North Atlantic since the Last Glacial Maximum from Blake Ridge sediments, Earth Planet. Sci. Lett., 266(1-2), 61-77, doi:10.1016/j.eps1.2007.10.037.

Gutjahr, M., B. A. A. Hoogakker, M. Frank, and I. N. McCave (2010), Changes in North Atlantic Deep Water strength and bottom water masses during Marine Isotope Stage 3(45 to 35 ka BP), Quat. Sci. Rev., 29(19-20), 2451-2461, doi:10.1016/j.quascirev.2010.02.024.

Haley, B. A., G. P. Klinkhammer, and J. McManus (2004), Rare earth elements in pore waters of marine sediments, Geochim. Cosmochim. Acta, 68(6), 1265-1279, doi:10.1016/j.gca.2003.09.012.

Hemming, S. R. (2004), Heinrich events: Massive late pleistocene detritus layers of the North Atlantic and their global climate imprint, Rev. Geophys., 42, RG1005, doi:10.1029/2003RG000128.

Hodell, D. A., J. E. T. Channell, J. H. Curtis, O. E. Romero, and U. Rohl (2008), Onset of "Hudson Strait" Heinrich events in the eastern North Atlantic at the end of the middle Pleistocene transition (similar to 640 ka)?, Paleoceanography, 23, PA4218, doi:10.1029/2008PA001591.

Jeandel, C., T. Arsouze, F. Lacan, P. Techine, and J. C. Dutay (2007), Isotopic $\mathrm{Nd}$ compositions and concentrations of the lithogenic inputs into the ocean: A compilation, with an emphasis on the margins, Chem. Geol., 239, 156-164, doi:10.1016/j.chemgeo.2006.11.013.

Keigwin, L. D., and E. A. Boyle (2008), Did North Atlantic overturning halt 17,000 years ago?, Paleoceanography, 23, PA1101, doi:10.1029/ 2007PA001500

Keigwin, L. D., and G. A. Jones (1994), Western North Atlantic evidence for millennial-scale changes in ocean circulation and climate, J. Geophys. Res., 99(C6), 12,397-12,410, doi:10.1029/94JC00525.
Kennett, J. P., and N. J. Shackleton (1975), Laurentide Ice Sheet meltwater recorded in Gulf of Mexico deep-sea cores, Science, 188(4184), 147-150, doi:10.1126/science.188.4184.147

Klevenz, V., D. Vance, D. N. Schmidt, and K. Mezger (2008), Neodymium isotopes in benthic foraminifera: Core-top systematics and a downcore record from the Neogene south Atlantic, Earth Planet. Sci. Lett., 265(3-4), 571-587, doi:10.1016/j.eps1.2007.10.053.

Kurzweil, F., M. Gutjahr, D. Vance, and L. Keigwin (2010), Authigenic Pb isotopes from the Laurentian Fan: Changes in chemical weathering and patterns of North American freshwater runoff during the last deglaciation, Earth Planet. Sci. Lett., 299(3-4), 458-465, doi:10.1016/j.eps1.2010.09.031.

Lacan, F., and C. Jeandel (2005a), Acquisition of the neodymium isotopic composition of the North Atlantic Deep Water, Geochem. Geophys. Geosyst., 6, Q12008, doi:10.1029/2005GC000956.

Lacan, F., and C. Jeandel (2005b), Neodymium isotopes as a new tool for quantifying exchange fluxes at the continent-ocean interface, Earth Planet. Sci. Lett., 232(3-4), 245-257, doi:10.1016/j.eps1.2005.01.004.

Lambeck, K., A. Purcell, J. Zhao, and N. O. Svensson (2010), The Scandinavian Ice Sheet: From MIS 4 to the end of the Last Glacial Maximum, Boreas, 39(2), 410-435, doi:10.1111/j.1502-3885.2010.00140.x.

Licciardi, J. M., J. T. Teller, and P. U. Clark (1999), Freshwater routing by the Laurentide ice sheet during the last deglaciation, in Mechanisms of Global Climate Change at Millennial Time Scales, Geophys. Monogr. Ser., vol. 112, edited by P. U. Clark, R. S. Webb, and L. D. Keigwin, pp. 177-202, AGU, Washington, D. C.

Lippold, J., J. Grutzner, D. Winter, Y. Lahaye, A. Mangini, and M. Christl (2009), Does sedimentary ${ }^{231} \mathrm{~Pa} /{ }^{230} \mathrm{Th}$ from the Bermuda Rise monitor past Atlantic Meridional Overturning Circulation?, Geophys. Res. Lett., 36, L12601, doi:10.1029/2009GL038068.

Lynch-Stieglitz, J., et al. (2007), Atlantic Meridional Overturning Circulation during the Last Glacial Maximum, Science, 316(5821), 66-69, doi:10.1126/science. 1137127 .

Martin, E. E., and H. D. Scher (2004), Preservation of seawater Sr and Nd isotopes in fossil fish teeth: Bad news and good news, Earth Planet. Sci. Lett., 220(1-2), 25-39, doi:10.1016/S0012-821X(04)00030-5.

McManus, J. F., D. W. Oppo, and J. L. Cullen (1999), A 0.5-million-year record of millennial-scale climate variability in the North Atlantic, Science, 283(5404), 971-975, doi:10.1126/science.283.5404.971.

McManus, J. F., R. Francois, J. M. Gherardi, L. D. Keigwin, and S. BrownLeger (2004), Collapse and rapid resumption of Atlantic meridional circulation linked to deglacial climate changes, Nature, 428(6985), 834-837, doi:10.1038/nature02494.

Moros, M., A. Kuijpers, I. Snowball, S. Lassen, D. Backstrom, F. Gingele, and J. McManus (2002), Were glacial iceberg surges in the North Atlantic triggered by climatic warming?, Mar. Geol., 192(4), 393-417, doi:10.1016/S0025-3227(02)00592-3.

North Greenland Ice Core Project Members (2004), High-resolution record of Northern Hemisphere climate extending into the last interglacial period, Nature, 431(7005), 147-151, doi:10.1038/nature02805.

Pahnke, K., S. L. Goldstein, and S. R. Hemming (2008), Abrupt changes in Antarctic Intermediate Water circulation over the past 25,000 years, Nat. Geosci., 1(12), 870-874, doi:10.1038/ngeo360.

Payne, A. J., A. Vieli, A. P. Shepherd, D. J. Wingham, and E. Rignot (2004), Recent dramatic thinning of largest West Antarctic ice stream triggered by oceans, Geophys. Res. Lett., 31(23), L23401, doi:10.1029/ 2004GL021284

Peck, V. L., I. R. Hall, R. Zahn, H. Elderfield, F. Grousset, S. R. Hemming, and J. D. Scourse (2006), High resolution evidence for linkages between NW European ice sheet instability and Atlantic Meridional Overturning Circulation, Earth Planet. Sci. Lett., 243(3-4), 476-488, doi:10.1016/j. eps1.2005.12.023.

Piepgras, D. J., and G. J. Wasserburg (1987), Rare earth element transport in the western North Atlantic inferred from $\mathrm{Nd}$ isotopic observations, Geochim. Cosmochim. Acta, 51(5), 1257-1271, doi:10.1016/0016-7037 (87)90217-1.

Piotrowski, A. M., S. L. Goldstein, S. R. Hemming, and R. G. Fairbanks (2005), Temporal relationships of carbon cycling and ocean circulation at glacial boundaries, Science, 307(5717), 1933-1938, doi:10.1126/ science. 1104883 .

Rahmstorf, S. (2002), Ocean circulation and climate during the past 120,000 years, Nature, 419(6903), 207-214, doi:10.1038/nature01090.

Reimer, P. J., et al. (2009), INTCAL09 and MARINE09 radiocarbon calibration curves, 0-50,000 years cal BP, Radiocarbon, 51(4), 1111-1150.

Rignot, E., M. Koppes, and I. Velicogna (2010), Rapid submarine melting of the calving faces of West Greenland glaciers, Nat. Geosci., 3(3), 187-191, doi:10.1038/ngeo765.

Roberts, N. L., A. M. Piotrowski, J. F. McManus, and L. D. Keigwin (2010), Synchronous deglacial overturning and water mass source changes, Science, 327(5961), 75-78, doi:10.1126/science.1178068. 
Robinson, L. F., J. F. Adkins, L. D. Keigwin, J. Southon, D. P. Fernandez, S. L. Wang, and D. S. Scheirer (2005), Radiocarbon variability in the western North Atlantic during the last deglaciation, Science, 310(5753), 1469-1473, doi:10.1126/science. 1114832 .

Sarnthein, M., K. Winn, S. J. A. Jung, J. C. Duplessy, L. Labeyrie, H. Erlenkeuser, and G. Ganssen (1994), Changes in east Atlantic deep water circulation over the last 30,000 years: Eight time slice reconstructions, Paleoceanography, 9(2), 209-267, doi:10.1029/93PA03301.

Scourse, J. D., I. R. Hall, I. N. McCave, J. R. Young, and C. Sugdon (2000), The origin of Heinrich layers: Evidence from $\mathrm{H} 2$ for European precursor events, Earth Planet. Sci. Lett., 182(2), 187-195, doi:10.1016/ S0012-821X(00)00241-7.

Scourse, J. D., A. I. Haapaniemi, E. Colmenero-Hidalgo, V. L. Peck, I. R. Hall, W. E. N. Austin, P. C. Knutz, and R. Zahn (2009), Growth, dynamics and deglaciation of the last British-Irish ice sheet: The deepsea ice-rafted detritus record, Quat. Sci. Rev., 28(27-28), 3066-3084, doi:10.1016/j.quascirev.2009.08.009.

Shepherd, A., D. Wingham, and E. Rignot (2004), Warm ocean is eroding West Antarctic Ice Sheet, Geophys. Res. Lett., 31, L23402, doi:10.1029/ 2004GL021106.

Svensson, A., et al. (2006), The Greenland Ice Core Chronology 2005, 15-42 ka. Part 2: Comparison to other records, Quat. Sci. Rev., 25(23-24), 3258-3267, doi:10.1016/j.quascirev.2006.08.003.

Tachikawa, K., V. Athias, and C. Jeandel (2003), Neodymium budget in the modern ocean and paleo-oceanographic implications, J. Geophys. Res., 108(C8), 3254, doi:10.1029/1999JC000285.

Tarasov, L., and W. R. Peltier (2005), Arctic freshwater forcing of the Younger Dryas cold reversal, Nature, 435(7042), 662-665, doi:10.1038/ nature03617.

Thomas, A. L., G. M. Henderson, and L. F. Robinson (2006), Interpretation of the ${ }^{231} \mathrm{~Pa} /{ }^{230} \mathrm{Th}$ paleocirculation proxy: New water-column measurements from the southwest Indian Ocean, Earth Planet. Sci. Lett., 241(3-4), 493-504, doi:10.1016/j.eps1.2005.11.031.
Thornalley, D. J. R., S. Barker, W. S. Broecker, H. Elderfield, and I. N. McCave (2011), The deglacial evolution of North Atlantic deep convection, Science, 331(6014), 202-205, doi:10.1126/science.1196812.

van de Flierdt, T., L. F. Robinson, J. F. Adkins, S. R. Hemming, and S. J. Goldstein (2006), Temporal stability of the neodymium isotope signature of the Holocene to glacial North Atlantic, Paleoceanography, 21, PA4102, doi:10.1029/2006PA001294.

van de Flierdt, T., L. F. Robinson, and J. F. Adkins (2010), Deep-sea coral aragonite as a recorder for the neodymium isotopic composition of seawater, Geochim. Cosmochim. Acta, 74(21), 6014-6032, doi:10.1016/j. gca.2010.08.001.

Vance, D., and M. Thirlwall (2002), An assessment of mass discrimination in MC-ICPMS using Nd isotopes, Chem. Geol., 185(3-4), 227-240, doi:10.1016/S0009-2541(01)00402-8.

Veiga-Pires, C. C., and C. Hillaire-Marcel (1999), U and Th isotope constraints on the duration of Heinrich events $\mathrm{H} 0-\mathrm{H} 4$ in the southeastern Labrador Sea, Paleoceanography, 14(2), 187-199, doi:10.1029/1998PA900003.

von Blanckenburg, F. (1999), Tracing past ocean circulation?, Science, 286(5446), 1862-1863, doi:10.1126/science.286.5446.1862b.

Zahn, R., J. Schonfeld, H. R. Kudrass, M. H. Park, H. Erlenkeuser, and P. Grootes (1997), Thermohaline instability in the North Atlantic during meltwater events: Stable isotope and ice-rafted detritus records from core SO75-26KL, Portuguese Margin, Paleoceanography, 12(5), 696-710, doi:10.1029/97PA00581.

M. Gutjahr, School of Ocean and Earth Sciences, National Oceanography Centre, University of Southampton, European Way, Southampton SO14 3ZH, UK. (m.gutjahr@soton.ac.uk)

J. Lippold, Heidelberg Academy of Sciences, Institute of Environmental Physics, University of Heidelberg, Im Neuenheimer Feld 229, Heidelberg D-69120, Germany. 